\title{
Soviet Design: A Comment and an Alternative View
}

The study of Soviet design is an area where knowledge of science, technology, art; and history need to converge; a discussion of it, therefore, seems particularly appropriate for the pages of an interdisciplinary journal. The comments below are offered in the hopes of fostering further discussion across disciplines. In his article, Dr. Hutchings has gone beyond the conclusions of his book (Soviet Science, Technology, Design) to make some rather bold claims for the importance of studying Soviet design as a way of understanding major Soviet problems. $\mathrm{He}$ is to be commended for focusing attention on an area which has not received, at least until recently, much attention from Western scholars. Both his book and the article under discussion add some interesting ideas to the growing Western literature on the Soviet innovation process. There are, however, some basic difficulties in the way he conceptualizes and analyzes the problem of design, and the degree to which his conclusions are solidly supported by evidence. I will try to point out some of these problems by focusing on three areas of his essay: (1) his definition and use of terms, particularly the key concept of "design," (2) Soviet "neglect of design" and its causes, and (3) some of the major consequences he attributes to this neglect. In so doing, I will try to develop an alternative way of viewing this subject, based both on my own recent work concerning the relationship between technology and Soviet society and the work of other Western scholars who have published in this area. My view will be presented primarily as a hypothesis, since the evidence for it would require more extensive treatment than can be developed in a short comment. However, I will suggest where some of the evidence can be found and what areas of research need to be pursued to support more fully an alternative view.

(1) Definitions. At times one needs the agility, intellectually, of a fox to follow the author's argument. One reason for this is his ambiguous terminology. Dr. Hutchings's essay causes the reader a good deal of confusion because of his lack of a clear distinction from the outset between design in its broadest definition (design which "attends to the composition and arrangement of these components [for manufacture] as well as to the appearance and balance of qualities of the assembled product, with a view to satisfying consumers and users"), and the narrower meaning of what is called "industrial design" in the West. The latter relates more specifically to the external appearance of a product and the man-machine interface, that is, the degree to which a product is designed for its most efficient human use. The broader meaning of design includes both engineering design and aesthetic design; that is, engineering design is what Dr. Hutchings calls the "composition and arrangement" of physical components of a product, and aesthetic design relates to the "appearance and balance of qualities of the assembled product." The confusion arises in part from the fact that at times Hutchings is discussing design in its broadest meaning, at times he is talking about industrial design, and at times specifically about aesthetic design. He does 
not always make the reader aware of the distinctions as he switches from one type of design to another. He even extends his definition to include buildings and monuments, the Russian Ballet, and abstract art. The latter two areas seem to have little if anything to do with design as part of an industrial process (that is, the creation of products for manufacture) which $I$ take to be his primary focus. If there is such a direct connection, he fails to make it clear and support it adequately. "Design" becomes a catchall phrase so general as to remain, if not meaningless, at least very fuzzy. A good example of the confusion which stems from his discussion of the various levels of design arises in the section on the Soviet institute, VNIITE. Hutchings leaves the impression that VNIITE was set up as the central design headquarters for the Soviet Union-a coordinating body for all types of Soviet design-whereas Soviet materials as well as his own book make it clear that VNIITE is a coordinating body for only one type of design: industrial design. ${ }^{1}$ Design in the broadest definition has always been, and remains, relatively decentralized among hundreds of scientific-research institutes, project-planning institutes, and design bureaus. ${ }^{2}$ The Russian language avoids much of this confusion by using different words for these various forms of "design," and the author would have helped his readers by referring to these terms.

The relatively recent attention devoted to industrial design in the Soviet Union and its Western origins is indicated by the recent borrowing of a Western term. The word dizain in Russian refers specifically to industrial design. "Technical aesthetics" (tekhnicheskaia estetika) is considered the body of theory underlying this type of design. Such terms were not even included in the second edition of the Great Soviet Encyclopedia published in the early 1950s, whereas they are given extensive treatment in the new third edition. ${ }^{3}$ In Russian, design in the broader sense, and engineering design specifically, are referred to by a different, much older, term, konstruirovanie, dating back at least to the early years of Soviet industrialization. This kind of designer is a konstruktor who may work in a konstruktorskoe biuro. Whereas the field of industrial design in the 1960s employed only some 1800 persons (apparently both professional and nonprofessional) in VNIITE and its network of affiliated institutions, ${ }^{4}$ already by 1960 the various design organizations (konstruktorskie) employed an estimated 230,000 persons; and some 81,000 of these were professionals with higher education. ${ }^{5}$ The actual number of designers in the broader sense scattered throughout various Soviet institutions in the 1960 s was undoubtedly much greater. Thus VNIITE and its affiliates represented only a small proportion of the overall number of designers in the Soviet economy.

"Design" in its fuller meaning is conceived in Soviet definitions as part of the development process (proektirovanie, generally translated as project planning

1. See, for example, V. L. Glozychev, O dizaine (Moscow, 1970); Bol'shaia sovetskaia entsiklopediia, 3rd ed., vol. 25 (Moscow, 1976), pp. 527 and 534 (hereafter cited as BSE); Trudy VNIITE: Tekhnicheskaia estetika, vols. 1-9 (Moscow, 1971-75).

2. See G. M. Dobrov, ed., Organizatsiia nauki (Kiev, 1970) ; BSE, vol. 24 (Moscow, 1977), pp. 989 ff.; Alexander Korol, Soviet Rescarch and Development (Cambridge, Mass.: M.I.T. Press, 1965), pp. 61-71.

3. Great Soviet Encyclopedia, vol. 8 (New York, 1975), p. 155; BSE, vol. 25, pp. 527-28.

4. According to Hutchings's figures for 1971, in Raymond Hutchings, Soviet Science, Technology, Design (London, 1976), p. 156.

5. Korol, Soviet Research and Development, p. 68. 
or development).$^{6}$ Dr. Hutchings never uses the term development; and herein lies part of his conceptual difficulty. He considers design essentially a distinct element, separate from, though somehow connected with, science and technology. (His definition of technology is never made clear but seems, in context, to stand for production technology.) An alternative view which makes more sense to me is to view design in its broadest sense as part of the innovation process, not nearly so distinct or separable from science or technology as Hutchings would have us believe.

Hence, an alternative view would define design as part of a continuum, designated as the process of technological innovation. Scientific research, development, and production are the major parts of the process, with design seen as an activity that takes place primarily in the development-production part of the continuum. ${ }^{7}$ The process of innovation in its fullest spectrum leads from basic research to applied research to development and finally to production. A focus on development overall, rather than design alone, is a more meaningful way of conceptualizing Soviet problems with innovation. Traditionally, development has been conceded by Soviet sources to be the weakest link in the chain leading from scientific research to successful production; and design is important primarily as part of the development-production interface. In other words, I think Hutchings exaggerates its importance as a separate element rather than as part of a more general process.

Hutchings does not refer to Peter Solomon's recent essay, which provides a clearer definition of the process of technological innovation and an interesting historical interpretation for its weakness. ${ }^{8}$ (In general, Hutchings ignores much of the recent Western literature on Soviet innovation which would have been relevant to his discussion. ${ }^{9}$ ) Solomon writes that the term "technological innovation" "refers to the process through which scientific knowledge is translated into new products or processes which are then utilized in the productive process. Thus, innovation refers to more than either research or invention. Although both research and invention represent sources of new ideas, these ideas must then be

\section{2).}

6. BSE, vol. 21 (Moscow, 1975), p. 39; P. I. Orlov, Osnovy konstruirovaniia (Moscow,

7. According to Korol, "A longstanding difficulty in defining research and development, of course, has been the location of the 'cut-off point' between development and production. There is substantial acceptance of the core of research and development activity as comprising 'systematic and intensive study directed toward a fuller knowledge of the subject studied and use of that knowledge directed toward the production of useful materials, devices, systems, methods, or processes.' Differences exist as to whether such further activities as the design and development of prototypes are 'development' or 'production.' Design was excluded from the definition of research and development in the surveys of the Federal Government and the colleges and universities but the industry survey employed a concept which included it ..." (Reviews of Data, National Science Foundation 58-9 [February 1958], p. 3, cited in Korol, Soviet Research and Development, p. 67).

8. Peter H. Solomon, Jr., "Technological Innovation and Soviet Industrialization," in Mark Field, ed., The Social Consequences of Modernization in Communist Societies (Baltimore: The Johns Hopkins University Press, 1976).

9. For example, Joseph Berliner, The Innovation Decision in Soviet Industry (Cambridge, Mass.: M.I.T. Press, 1976) ; Bruce Parrott, "Technological Progress and Soviet Politics," in John R. Thomas and Ursula M. Kruse-Vaucienne, eds., Soviet Science and Technology (Washington, D.C.: National Science Foundation, 1977); OECD, Science Policy in the USSR (Paris, 1970); and Ronald Amann, Julian Cooper, and R. W. Davies, The Technological Level of Soviet Industry (New Haven: Yale University Press, 1977). 
translated into new products or processes; and this translation requires further 'development' activities, such as the designing, construction, and testing of models and the preparation of experimental production runs." 10

(2) Soviet neglect of design and its causes. I would agree that original Soviet design in the broadest sense of that term has been neglected for much of Soviet history in favor of borrowing and adapting foreign technology. ${ }^{11}$ But one could argue from the evidence in Korol, for example, that the Soviet design effort has not been neglected but somewhat favored (at least for the 1950-60 decade, to which Korol's data relate); that is, in that period professional manpower (specialists with higher education) assigned to Soviet design (konstruirovanie) was larger in comparison to the proportion of such specialists in the Soviet economy overall, as was the amount of money expended per specialist assigned to design organizations as compared with such allocations to scientific-research organizations. ${ }^{12}$ More recent figures have not been found; but the point is that for Hutchings's argument to be persuasive, he needs to back up sweeping generalizations with more solid evidence.

What specifically does Hutchings mean, then, by Soviet "neglect of design"? To persuade the reader that the Soviet design effort overall has been neglected relative to scientific research and production technology, one needs, at the very least, quantitative data, including extensive time series data concerning the numbers and qualifications of personnel and monetary investments in each of these sectors. To provide perspective, comparisons with relevant investments of personnel and money in each of these sectors for other industrial countries would be helpful. Yet Hutchings indicates that such data for the USSR design effort are lacking: "in regard to quantity of design (reckoned either in amount or in the effort absorbed by it), data over any sustained period are lacking." Without this evidence, words such as "neglect" remain at best impressionistic.

On the basis of other kinds of evidence one can make a stronger case that original Soviet design has been neglected in favor of borrowing and adaptation of foreign technology, but this is not a particularly new or astounding conclusion and needs to be somewhat modified for more recent years, based on the extensive materials found in the recently published book by Amann, Cooper, and Davies, ${ }^{13}$ which, in fact, calls into question Hutchings's concluding statement that 'there appears to be much evidence of a widening gap between Soviet and advanced Western technical levels" (emphasis added). The situation would appear to be much more complex and uneven and needs to be examined on an industry-by-industry basis, as Amann, Cooper, and Davies have done. Where wide gaps still exist

10. Solomon, "Technological Innovation," pp. 207-8.

11. See, for example, Antony C. Sutton, Western Technology and Soviet Economic Development, 3 vols. (Stanford, 1968-73), which perhaps overstates this point, and also Bruce Parrott, "Technology and the Soviet Polity: The Problem of Industrial Innovation, 1928 to 1976" (Ph.D. diss., Columbia University, 1976).

12. Korol, Soviet Research and Development, pp. 66 and 220. My own figures for Soviet industry in 1941 would indicate that design employed a larger proportion of graduate technologists than industrial scientific-research institutes (see Kendall E. Bailes, Technology and Society Under Lenin and Stalin: Origins of the Soviet Technical Intelligentsia [Princeton: Princeton University Press, 1978], p. 336).

13. Amann, Cooper, and Davies, The Technological Level of Soviet Industry, p. 66. 
between Soviet and Western technological levels, it seems doubtful that "neglect" of Soviet design alone is the primary cause. I will suggest other causes below.

An argument for the neglect of design in a narrower sense-that is, industrial design-has a much more solid case based on both quantitative and qualitative data, including the statements of authoritative Soviet specialists. ${ }^{14}$ In fact, I think that the more interesting problem in the area of Soviet design is to explain why industrial design was largely neglected until the early $1960 \mathrm{~s}$, despite some promising beginnings in the 1920s. Dr. Hutchings's essay and book provide the materials for a partial explanation. I would like to suggest a somewhat fuller explanation for which evidence exists, but which needs to be tested by additional research: The reason for the neglect of Soviet industrial design was the relative shortage of well-trained and highly experienced technical specialists in this area, combined with the enormous emphasis historically on meeting high quantitative targets and the neglect of market forces under centralized planning. Hutchings touches on the latter two factors but neglects the first. What we need is more focus on the historical development of the technical professions in the Soviet Union-their size, growth, the relative emphasis given to various specialties, and the historically conditioned attitudes and patterns of behavior of these groups. ${ }^{15}$

An alternative approach would argue that one reason for the revival of interest in industrial design was the production (by the early 1960s) of unsold surpluses in certain areas of industry, combined with the growth of technical cadres and surpluses of technical specialists in some sectors. The overcrowding of specialists, particularly in R \& D (where the most qualified Soviet technologists have preferred to work) rather than in production, ${ }^{16}$ led some enterprising members of the Soviet technical intelligentsia to borrow from the West an emphasis on industrial design. They essentially seized the opportunity to meet a need which had not existed earlier. By the early 1960s, the Soviet economy had matured to a point where it needed to pay more attention to market forces when industry could no longer sell everything it produced.

Here a comparative perspective, which is lacking in Hutchings's essay, might be valuable. Industrial design first arose in the West during the early twentieth century with the introduction of new mass production techniques and increased competition for sales. ${ }^{17}$ That is, industrial designers who combined art with technology could produce more aesthetically attractive goods. Industrial designers also applied the new field of ergonomics to create designs which allowed more efficient adaptation of products to human use. ${ }^{18}$ These two factors enhanced the marketability of goods and therefore the competitive edge of the companies which employed them. While official Soviet definitions of industrial

14. See Iu. B. Solov'ev's article in $B S E$, vol. 25 , pp. 527-28.

15. This is the approach I have attempted for the period 1917-41 (see Bailes, Technology and Society Under Lenin and Stalin) and in an essay on the post-Stalin period (see Bailes, "Soviet Engineers: Social Roles and Attitudes," in Susan Solomon and Linda Lubrano, eds., Soviet Science and Technology in Social Context [Boulder, Colo.: Westriew Press, forthcoming 1979]).

16. The evidence for this can be found in Bailes, "Soviet Engineers."

17. Nikolaus Pevsner, Pioneers of Modern Design (New York, 1949); and Sigfried Giedion, Mechanization Takes Command (New York, 1948).

18. Ergonomics is defined as "the study of human capability and psychology in relation to the working environment and the equipment operated by the worker" (McGraw-Hill Dictionary of Scientific and Technical Terms [New York, 1976], p. 505). 
design under socialism deny that the same motive of enhanced marketability gives impetus to the growth of this field in the Soviet Union, we need more solid evidence than that given by Hutchings on the actual types of work Soviet industrial designers are engaged in. ${ }^{19}$ Is their work, in fact, concentrated in areas which have suffered from marketing problems? In his book, for example, Hutchings tells us that 60 percent of the income for VNIITE in the 1960s came from contracts with Soviet firms, but it would be valuable to know more precisely the nature and areas of such contracts and whether there have been any appreciable changes in contract work since his book appeared.

In general, an alternative view would emphasize that only in the past two decades have the Soviets both had the need for and been able to afford the resources for industrial design. The same would hold true for more original engineering designs. In earlier years, it was simply more economical to concentrate their $\mathrm{R} \& \mathrm{D}$ and productive resources on borrowing and adapting foreign designs to meet pressing Soviet needs than to develop their own from scratch, except in high-priority areas of heavy industry and national defense, where too heavy a reliance on copying was more difficult and potentially more dangerous to Soviet security. In this case, more original design activity can be found, although even here borrowing has been extensive, perhaps less so than Hutchings would at times lead us to believe, however. ${ }^{20}$

(3) Consequences of "Neglect of Design." Near the beginning of his essay, Hutchings states that "areas of material production where the USSR is backward typically have been and are those where the necessary input from design is large relative to the necessary inputs from science and technology." For the former area he cites computers, small chemicals, autos, textiles, handicrafts, and instrumentation, and for the latter, ferrous metallurgy, coal, oil, and electric power. The heart of his argument here seems to be that Soviet neglect of design in its broadest sense accounts for Soviet retardation in the first area and relative advancement in the second, where less design effort is supposedly needed. His argument, however, is like a house of cards. It collapses on at least two accounts: I see no proof whatsoever that computers, autos, textiles, and so forth require more design effort than steel mills, electric power production and transmission, petroleum drilling and refining, and so forth. How, in fact, does one measure the design effort required in such disparate areas and show that the former area

19. According to Solov'ev, "the close connection of technical aesthetics with social practice leads to the conclusion that the status of this discipline is very different in different social conditions. Contemporary capitalist society, on the one hand, must develop technical aesthetics and use its achievements since they have a direct influence on the competitive capability of practically all branches of industry. ... In contrast to this, under socialism, technical aesthetics plays a valuable role in the creation of the best conditions for work, daily life, and the leisure of people, in the upbringing of a harmoniously developed person, his communist relationship to the material, cultural, and aesthetic values. Technical aesthetics directly participates in the formation of conditions in which 'the artistic principle more and more inspires labor, beautifies daily life and ennobles people'" (Programma KPSS, 1976, p. 130) (cited in $B S E$, vol. 25, p. 528).

20. For example, Hutchings leaves the impression that the Soviet T-34 tank was copied largely from the Christie tank, whereas David Holloway indicates a number of original Soviet elements in the design of this tank (see Holloway in Amann, Cooper, and Davies, The Technological Level of Soviet Industry, pp. 419-21). 
necessarily requires more design than the latter? Perhaps it is possible, but Hutchings offers no such proof, and the generalization seems dubious to me. Second, even if one could offer such proof, Hutchings's case for a serious Soviet neglect of design effort in its broadest sense remains unproven because of the absence of sufficient data.

At the end of his essay, the author claims that Soviet neglect of design can illuminate a host of Soviet problems, including the gap between the civilian and military sectors of the Soviet economy and problems with technological innovation that slow down the process of substituting "intensive for extensive sources of growth." Since overall Soviet neglect of design has not been proven in his essay, where then should we look for an explanation of these phenomena? Even if overall Soviet neglect of design were proven and even if one could show that such neglect was a primary cause of major Soviet problems, this would, I think, only raise a more fundamental question: What caused such neglect? Soviet neglect, whether of industrial design or design in its broadest sense, is a symptom of something deeper: underlying systemic causes whose origins must be sought in a broader historical analysis. For example, one could argue that the more advanced areas of industry which Hutchings mentions are simply those that have received highest priority in Soviet planning and allocation of material and human resources. Why is this so? The kind of historical, economic, and social structural analysis offered by Solomon, Berliner, Parrott, and others seems ultimately to offer a fuller and more satisfying explanation of many of the phenomena Hutchings sets out to explore. ${ }^{21}$

In terms of evidence, Hutchings would be on more solid ground had he confined his efforts first to industrial design, where he has found a good deal of interesting material and has some suggestive hypotheses which need further exploration (for example, horizontalism/verticalism, Soviet largeness of scale). A more concrete study of Soviet industrial design as embodied in manufactured products would be a valuable service to our understanding of Soviet culture. What trends in industrial design can be noted since the founding of VNIITE in 1962? What is the mix of foreign and native influences in Soviet industrial design? How important is art relative to ergonomics in the work of Soviet industrial designers? How does Soviet industrial design illuminate broader areas of Soviet daily life and culture ?22 $^{22} \mathrm{Dr}$. Hutchings is uniquely qualified to offer answers to such questions in further essays, more conceptually focused and concretely supported than the present article.

21. See the sources cited in notes 8,9 , and $\mathbf{1 5}$.

22. Answers to such questions could be sought in more analysis of such Soviet periodicals as Dekorativnoe iskusstvo SSSR and Tekhnicheskaia estetika; and in K. M. Kantor, Krasota $i$ pol'za (Moscow, 1967) and V. L. Glozychev, $O$ dizaine. Of these sources, only the journal Tekhnicheskaia estetika is cited in the bibliography of Hutchings's book. 